\title{
Tiny Houses: Planetary Protection-Focused Materials Selection for Spaceflight Hardware Surfaces
}

\author{
D.E. (Betsy) Pugel \\ NASA Headquarters \\ 300 E Street SW \\ Washington DC 20024-3210 \\ 202-358-4486 \\ Betsy.Pugel@nasa.gov
}

\author{
J.R. Rummel \\ SETI Institute \\ P.O. Box 2838 \\ Champlain, NY 12919 \\ 508-523-1317 \\ jrummel@seti.org
}

\author{
Catharine Conley \\ NASA Headquarters \\ 300 E Street SW \\ Washington DC 20024-3210 \\ 202-358-3912 \\ Cassie.Conley@nasa.gov
}

\begin{abstract}
When developing spaceflight hardware, an engineering team is faced with a broad range of materials selections for design trade studies. Typical trade studies hone in on materials selection with thermal or mechanical environmental requirements as design selection drivers. With the growing interest in spaceflight hardware development for life-detection and restricted sample return missions, materials selection processes during the design phase will need to factor in the impact that materials selection will have on the growth of terrestrial microbes in the pre- and post-launch environment. From a planetary protection point of view, during the design and pre-fabrication processes, materials choices (composition, termination, finish) can result in surfaces that have the potential to support, sustain, or senesce microbes. We evaluate known surface properties of common spaceflight materials choices in the context of planetary protection considerations for future sample return and life-detection missions.
\end{abstract}

\section{TABLE OF ConTents}

1. INTRODUCTION ..................................................... 1

2. TERMINOLOGY (................................................... 2

3. TAKING A CENSUS .................................................. 3

4. Moving INTO A NEIGHBORHOOD: AdHESION

AND PlanETARY PROTECTION .................................... 3

5. Size MatTers: EfFects OF Feature Size

SCALE ON MICROBIAL ADHESION .............................. 4

6. SQuare Peg, Round Hole: EfFects of

GEOMETRY ON MICROBIAL ADHESION..................... 4

7. HOUSE OF STRAW OR BRICK? COMMON

SPACEFLIGHT MATERIALS

8. They ATE US OUT OF House AND HoMe:

MICROBIALLY-INDUCED CORROSION...................... 8

9. BLOW THIS HOUSE DOWN: FACTORING IN SIZE

Scales When Selecting Cleaning Methods... 9

10. SUMMARY ... 9

ACKNOWLEDGEMENTS

... 9

REFERENCES..........ERROR! BOOKMARK NOT DEFINED. ACKNOWLEDGEMENTS ............................................. 9

REFERENCES........................................................ 9

BIOGRAPHY

\section{INTRODUCTION}

In the spaceflight hardware development environment, the realm of biology is often left to the scientists, with little overlap with day-to-day engineering implications. When that overlap does occur, for the sake of compliance with NASA and external requirements for Planetary Protection (NPR 8020.12), a culture collision is often observed - the predictive nature of engineering does not always mesh well with the non-linear and organic realm of biology.

The biological structures that concern Planetary Protection cannot be readily modeled by conventional physics and engineering modeling approaches. A microbe is not a rigid spherical particle, it is a living entity that has genetically triggered signaling promoting growth, reproduction, senescence, and death. By virtue of being alive, it can increase its mass by growing or reproducing or somewhat decrease its mass (or ability to increase mass) temporarily by senescence/dormancy or permanently in death. The triggers for those genetic signals are not well-understood to the level to promote predictability for cycles of growth, death or senescence, whether on Earth or in an extreme environment that may be encountered on a planetary mission.

The living nature of an organism lacks the comfortable predictive option that a block of aluminum would have. A block of aluminum has no genetic triggers and its mass and volume are visibly and comfortably well-within the control of the designer. Microbes, the denizens of microbiology, can change mass and volume and elude our immediate human vision while doing so.

This article intends to be a light-hearted introduction to microbiology, with the application of planetary protection and materials selection for spaceflight hardware. The article focuses on for engineers and scientists looking to better understand how to tailor their materials selection process and provides a practical introduction to the day-to-day design and implementation concerns during materials selection that may be encountered during a spaceflight project that contains planetary protection requirements. 


\section{TERMINOLOGY}

Many engineers and scientists working on spaceflight hardware use biology terms interchangeably, so it's worth taking a moment to define them, as they are substantially different to a microbiologist or local planetary protection team member on a flight project:

Microoorganism
Microbe
Bacteria
Cell
Spore
Virus
Strain
Biofilms
Planktonic
Sessile

At the broadest level, a microorganism is what its name directly claims: a micron-scale size organism. This organism could be a bacterium, some fungi and algae and some other categories of critters (archaea and protozoa, we'll get to them in a moment). A microbe is synonymous with a microorganism. Bacteria are one kind of microorganism, Fungi, another kind.

The temptation to call micron-sized microbes "particles" is likely a strong one for the non-biologically inclined, as it simplifies biology down to a system of particles with variable size scales. This approach hearkens back to the $19^{\text {th }}$ century, pre-germ theory, wherein microscopic living organisms were hypothesized as particles, subject to the whims of winds, unable to move on their own, grow or die. Just as biology has advanced by two centuries worth of understanding, the interaction of living organisms on spacecraft surfaces must be seen and modeled as more than static micron-sized particles.

Living microorganisms have a structure, a cell that holds them together. If the environment is not right for growth and reproduction, many microorganisms go dormant and exist as spores (bacterial, fungal, etc.). Spores are structurally different from living cells, since spore structures are designed to protect the internal contents of a viable microorganism from unfavorable conditions until favorable conditions appear and signal a release out of dormancy. Until then, they lie dormant with an exterior coating that is suitable for protecting them until the environmental conditions are right, which in some cases has been observed to be thousands of years [1]. In the majority of instances, spore coatings have been found to be adaptive to the local environment. The impressive and varied mechanisms for adaptation is an area of ongoing study.

Viruses are different from bacteria and other microorganisms. Here's the difference: bacteria can live with or without a host, viruses need a host. Viruses are devoid of reproductive machinery, they can't reproduce on their own and so, they need a host.

A simplified Tree of Life is composed of:

- Bacteria

- Eukarya (fungi, plans, slime molds and other critters)

- Archaea

Notice that viruses aren't on that tree. They're a subset unto themselves. Because they are so simple, many biologists consider viruses a potentially very hardy species that could survive. We won't be talking about viruses in this article, since NASA requirements don't currently require census taking of these critters. From a biological point of view, we note that the majority of spaceflight microbiologists and astrobiologists agree that viruses are among the hardier critters out there and have been speculatively proposed as sources of cross-fertilization between planetary bodies [2] From our practical standpoint, we'll consider bacterial cells, bacterial and fungal spores, and lichens, since these populations are part of the NASA census (assay) requirement.

On that tree are extremophiles, organisms that could be Bacteria, Archaea or Eukarya. Extremophiles can survive in extremes of temperature, pressure, $\mathrm{pH}$, and other conditions, relative to what human engineers are used to. These are the organisms that most planetary protection team members worry about. Extremophile microbiology is a relatively new field, so there are still many organisms that have not yet been found.

Just like people have different names and behave in different ways to different environments, so do all the critters we've discussed above. Strains are different genetic variations of the same microorganism. For example, if you go get an annual flu shot, each year, a different strain of the Influenza virus is identified as the strain to cause the greatest risk to the general population. The most common strains of Influenza are influenza A (H1N1), influenza A (H3N2), and influenza B. They're all genetically similar, but have some small variations Just as people have different names and behave in different ways when encountering different environments, so do all the critters we've discussed above.

Continuing through the list of terms at the start of this section, we come upon a term that represents a collective of cells, known as a biofilm. Biofilms arise from the actions of bacteria that encounter a substrate surface to condition the local environment for better cell adhesion. Mobile or freefloating bacteria, known as planktonic bacteria, may end up in a circumstance where they stop moving, becoming sessile, and attach to a surface. As they aggregate and multiply on a surface (along with other biological "mortar"), they change metabolically, often exerting and requiring less energy. This poorly-understood state of collective existence often imparts resistance to cleaning, sterilization and 
antibiotics, as seen in the marine (for example, biofouling on ships), medical, and dental industries (for example, films on teeth and medical devices such as catheters and stents) [3] [4].

From this section on terminology, it's clear that biology is a completely different realm when it comes to predictability and organization. It's not a science that lends itself well to the linear order of engineering or to common rule sets.

\section{TAKing a CEnSus}

Planetary Protection requirements are set by NASA based on destination and mission game plan. You can find more information at planetaryprotection.nasa.gov. Requirements limiting microbial burden are met by planetary protection engineers cleaning spacecraft surfaces and taking censuses of spore populations. Those censuses are known as assays. Much like going to the doctor, where your throat might be swabbed for strep and that swab would be cultured, planetary protection microbiologists conduct this level of effort, but not on your throat. They swab spaceflight hardware and culture it. The culture gives the planetary protection microbiologist an estimate of the cleanliness of a spacecraft surface much like taking a subsample-based survey of a community. The planetary protection engineering lead for a project is able to discern the number and, when needed, "demographics" of the area that has been sampled [5]. Spores are assayed for and counted since they represent the hardiest of the lot, able to survive the challenges of the space environment.

In any neighborhood, human or microbial, a population count depends on when it is conducted, how it is conducted, and who you're able to talk to when you conduct the census. A town that has experienced a natural disaster may have a low population, though your census won't tell you the number of houses that were there before the disaster hit or how many were left. The census just tells you who was there for two different points in time - not the mechanisms associated with the population change. Of course, if you have census data from before the natural disaster, you can figure out the population change and get a sense of the magnitude of the natural disaster. The equivalent statement for microbes is that we can't tell who survived cleaning a surface, unless we sampled before we cleaned. We do know from practical experience [6] that different choices for housing (for example, size or structure composition) lead to housing different numbers of inhabitants (studio apartments vs. mansions) and survivability of houses under natural disasters (for example, straw vs. brick). The same goes for microorganisms adhering to spacecraft hardware materials.

In this paper, we review the literature for kinds of relationships between microbial populations, spaceflight hardware materials choices and surface finishes (the cracks and crevices in which they can grow or be dormant). In the case of such minuscule organisms living in such tiny houses, their "natural disasters" are generated during the cleaning processes employed and how effective they are in removing (adhesion-based) or sterilizing (chemically-based) a surface.

\section{Moving InTO A NeIGHBorhood: AdHesion and Planetary Protection}

The actual mechanism for microbial adhesion is multifaceted. Microorganisms can move into a neighborhood by several different transport mechanisms, including: fluid flow (along the path of the local streams), sedimentation (progressively settling down), chemotaxis (sniffing your way in) and Brownian motion (randomly stumbling in). Once there, they set down their own version of roots and adhere. How they adhere depends on three main factors: the substrate, the surrounding fluid, and the microorganism itself.

In this paper, we focus on the substrate as it relates to the microorganism, with some references to the surrounding fluid. Physical properties of the substrate, such as surface finish, surface roughness, grade/chemical composition interact with properties of the microorganism, such as contact time with the surface, presence of cell appendages, surface charge, surface hydrophobicity, and metabolism. How this interaction and potential for adhesion happens is mediated by properties of the surrounding fluid, including its $\mathrm{pH}$, ionic composition and temperature.

The concern for planetary protection is the inability to either remove or sterilize microbes that have entered into the irreversible stage of adhesion, particularly for missions that have environments that would facilitate access to nutrients for cells to grow and divide (this includes surface features that may contain residual soils or organic matter as a result of ineffective cleaning or recontamination). When selecting materials, an engineer must learn that represents choices that may lead to suitable niche environments for microbes.

The majority of the literature discusses cells versus spores. While reading this review, keep in mind that what you'll be reading represents a much lower bound in terms of what is known for adhesion rate and resistance to cleaning and heat reduction, since we're primarily discussing cell results instead of spores. This is because in general, spores attach to a surface at greater rates than vegetative cells [7], [8], [9]. Once attached, spores show a greater resistance to environmental attack (heat, UV, etc.) than their vegetative counterparts. [10].

In addition, there is currently limited research on some of the more robust critters that are known to survive the harsh conditions of the spaceflight build, launch and land experience. The majority of the studies focus on Bacillus subtilis spores [11], [12]. The reader should keep in mind that this paper addresses those critters when information is available and addresses what is currently known about the behavior of microorganisms as studied outside of this realm for a broad variety of microorganisms. 
What makes a given surface an attractive home is the focus of the rest of this paper. Much like people finding their own residences, there is a great deal of variation that any engineer must be willing to accept in which microorganisms choose to live where and the mechanism behind this [13] "choice." For example, even within a single bacterial strain there can be substantial variation in adhesion mechanisms.

\section{Size Matters: Effects of Feature Size SCALE ON Microbial ADHESION}

Over the past 10 years, biologists have taken advantage of advances in micro and nanofabrication to conduct a range of controlled studies to isolate the effects of size and geometry on adhesion. These studies use microfabricated valleys and pillars of variable depth and height, respectively. Microorganisms that are larger or smaller than the microfabricated structures are placed in the array and observed. For a wide range of microorganisms (from bacteria to alga) and for a wide range of geometries and depths, results show that size matters: the relative dimensions of the substrate features and the microorganism set the stage for adhesion.

If a cell can fit into a groove or crevice on a surface, it is more likely to stick to a surface in comparison to a cell that is larger than a given surface feature [14]. If the size scale similar to or smaller than the dimensions of a given microbe, studies on engineered structures indicate that for regular features, microbes will not fit and are unlikely to survive [15], [16], [17]. For example, S. Aureus and E. Coli show reduced growth when periodic spacings of engineered pillars are reduced to less than $0.8 \mu \mathrm{m}$ [18], [19]. Listeria innocua, and Pseudomonas fluorescens. An average $S$. aureus, which is spherical, is about $0.6 \mu \mathrm{m}$. An average $E$. coli, which is rod shaped, is $0.5 \mu \mathrm{m}$ wide by $2 \mu \mathrm{m}$ long.

A common rule of thumb in the food industry is that surfaces with an average roughness $\left(\mathrm{R}_{\mathrm{a}}\right)$ of $\leq 0.8 \mu \mathrm{m}$ are deemed "hygienic," [20] as they are unable to sustain growth of surface microbes. Knowing this, selection of appropriate surface finishes for hardware that is critical to planetary protection (e.g. sample tubes or sample containers) may ease some of the risk associated in design and shorten testing timescales during the early phases of a project when different design trades are conducted.

In general, surface reactivity increases as roughness increases, based on surface area available for binding [21]. If that surface area is comparable to the size scale of a rigid cell or the associated binding regions of a cell, there is an increased chance of binding and a likelihood of increased retention time on a surface [22].

\section{Square Peg, Round Hole: Effects of GeOMETRy ON Microbial AdHESION}

In addition to size mattering, controlled studies on microfabricated structures also show that the old notion of not putting a square peg into a round hole goes out the door for some microorganisms. So, geometry matters, but only sometimes. Cross-sectional geometries of valleys and grooves and their orientations affect the binding potential, though in many cases the microorganism is able to deform and fit into a groove of a given geometry if the size scale of the substrate is appropriate to the size of the microorganism.

When designing hardware, we often concern ourselves with the topographical and topological variations (for example, joints, dead ends, and surface finishes) as they relate to mechanical, physical and chemical properties in the relevant spaceflight environment. To a microorganism, these geometric variations can be appealing real estate in the same way that the average human house hunter may be drawn in by the high ceilings of a foyer or living room. The difference from a human house hunter is that microbes are willing and able to reconfigure themselves, moving cytoplasmic contents to align with microscale and nanoscale surface features so as to maximize contact area. In addition, since not all microbes are spherical, they can rearrange themselves horizontally or vertically, relative to the aspect ratio of the features on a given surface. While we humans could hunch over and live our lives in a house with very low ceilings, the authors suspect that this would not make for as happy a home as it does for a microbe.

Some examples: P. fluorescens was observed to align itself lengthwise in $0.9 \mu \mathrm{m}$ wide channels structured into gold films, in order to accommodate its width relative to the structured channel width [23]. P. fluorescens is a rodshaped bacteria with dimensions of $0.5-1.0 \mu \mathrm{m} \times 1.5-5.0$ $\mu \mathrm{m}$ and selectively oriented itself in order to fit as compared to laying over two neighboring channels. $P$. aeruginosa, also a rod-like bacteria in the same family as $P$. fluorescens and the same range of dimensions (the " $P$ " here is for Pseudomonas) was observed to position itself depending on the dimensions and aspect ratios of engineered nanoposts. If the posts were placed far enough apart to fit the cells, they would align horizontally. If the spacing between the nanoposts was smaller than the diameter of the cells, they aligned vertically, parallel to the posts [24]. There are countless other examples in the literature of alignment of a wide range of microoorganisms over a wide range of materials and both engineered and unengineered surfaces.

At a larger scale of concern for geometric design effects for planetary protection missions. Any nook, cranny or dead end (for example, blind ends of tubes, threads of screws, valve seats)are prime real estate locations for microbial accumulation. These features often have limited access for cleaning or polishing to reduce surface finish or scratches. 
For similar reasons, maintenance of cleanliness can be difficult and accumulation of bioburden is more likely.

\section{HOUSE OF STRAW OR BRICK? COMMON SPACEFLIGHT MATERIALS}

We now know that size matters and sometimes geometry does too. What about composition? In the materials selection process, we often sweat the details of a particular material composition as it relates to radiation, thermal, humidity, launch loads, etc., though to be honest, most spaceflight missions really aren't used to worrying about materials composition as it relates to planetary protection. Below we provide a summary of common materials that we use in our missions, pointing out both size and composition relationships to adhesion of microorganisms.

\section{A. Non-Metals}

Given the surface hardness and the lack of porosity of most metals vs. non-metals, for the most part, metals are a more desirable materials class for designing with planetary protection in mind vs. non-metals. This is especially true when polymers, natural materials, glass and wood are considered. There are some ceramic materials and nonmetals that have natural antimicrobial properties to them, particularly in the presence of ultraviolet light exposure, though their investigation for use as antimicrobial surfaces for spaceflight hardware has been limited.

In the early days of planetary protection, long-duration survival studies were conducted on metals and non-metals. For non-metals such as cotton, glass, wood and paper, Shigella sonnei showed that it had the longest survival time at $-20^{\circ} \mathrm{C}$, shortest at $45^{\circ} \mathrm{C}$. [25] Serratia marcenses is at the other end of the moisture spectrum and needs either a great deal of water to survive or can go dormant in the face of no humidity and survive. You may know it as the pink stuff that might be growing in the grout in your shower. Microfabricated polydimethylsiloxane (PMDS) pillars, 10$\mu \mathrm{m}$ tall and ordered laterally square patterns with a range between $2-100 \mu \mathrm{m}$ range and periodicity between $5-20 \mu \mathrm{m}$ showed preferential adherence and biofilm formation in the valleys between the pillars.

Teflon is characterized by its hydrophobicity, giving rise to its non-stick pan application. For this reason, it might seem like a good idea to use Teflon for planetary protection applications. In the bacterial world, it has been seen that Teflon has been able to host microoorganisms that preferentially modify their surface energies in order to adhere and populate the Teflon surface. Strains that have survived on Teflon surfaces have been shown to be more hydrophobic than their non-Teflon adhered counterparts, demonstrating the adaptation to Teflon's hydrophobicity [26], [27].

Common spaceflight plastics, including Ultem, G-10 and Vespel are ripe areas for research. In general, the development processes of most resin-based systems involve a curing step that occurs at temperatures that exceed planetary protection dry heat sterilization processes. The risk comes in the post-cure handling of the material-from the time it is made to its delivery from the manufacturer to a group building the hardware. There is potential to adapt some of the work that is known from health care applications of Ultem for cleanability, to explore options for applicability of antimicrobial-impregnated plastics, and other options, though these would require examination of hardy organisms over a relevant environment (thermal, mechanical, radiation), akin to the qualification process for new spaceflight hardware. This is a ripe area for future planetary protection research.

\section{B. Metals}

Adhesion and survival of microbes on metal surfaces is well-studied for a range of bacteria, archaea, eukaryota and viruses [28], [29]. A wide-range of bacteria is able to survive for weeks on end on metal surfaces in conditions that are impressive and may not be vulnerable until the right host appears. For example: Pasteurella [Francisella] tularensis is able to survive for more than two weeks at elevated temperatures with no detectable humidity. Pasteurella is common to cat and dog nasal and oral mucosa and while non-pathogenic to them, it causes infections in humans when bit by a dog or cat.

Stainless Steel-Stainless steels (SS) are among the most commonly used material in the production of spaceflight hardware. Stainless steel is "stainless" as rust (iron oxides) do not form as ready, unlike with carbon steel. This is because of the presence of varying percentages of chromium, with a minimum of $13 \% \mathrm{Cr}$ needed to prevent rust. In the presence of oxygen, chromium generates a passivation layer of various chromium oxides on the surface, which is why, at a minimum $13 \%$ is added. Additional elements such as aluminum, copper, molybdenum, nickel, niobium, nitrogen, sulfur, selenium, silicon, tantalum and titanium can be alloyed with stainless steel in order to give rise to different properties.

There is a system for alloy standardization system that reflects compositional and structural variations [30]. The 200 and 300 series are austentitic and the 400 series are ferritic and martensitic.

The selection of different grades of stainless steel can lead to different adhesion behaviors of microorganisms based on different surface chemistries. In addition, as we will see in a later section, microorganisms can actually metabolize the surfaces of stainless steel, leading to microbially-induced corrosion.

In medicine, spaceflight, and the food industry, grades 302, 304, and 316 are the most commonly used. Both 304 and 316 can be produced with reduced carbon levels, so they are referred to as the L-series (304L and 316L). 316 is different 


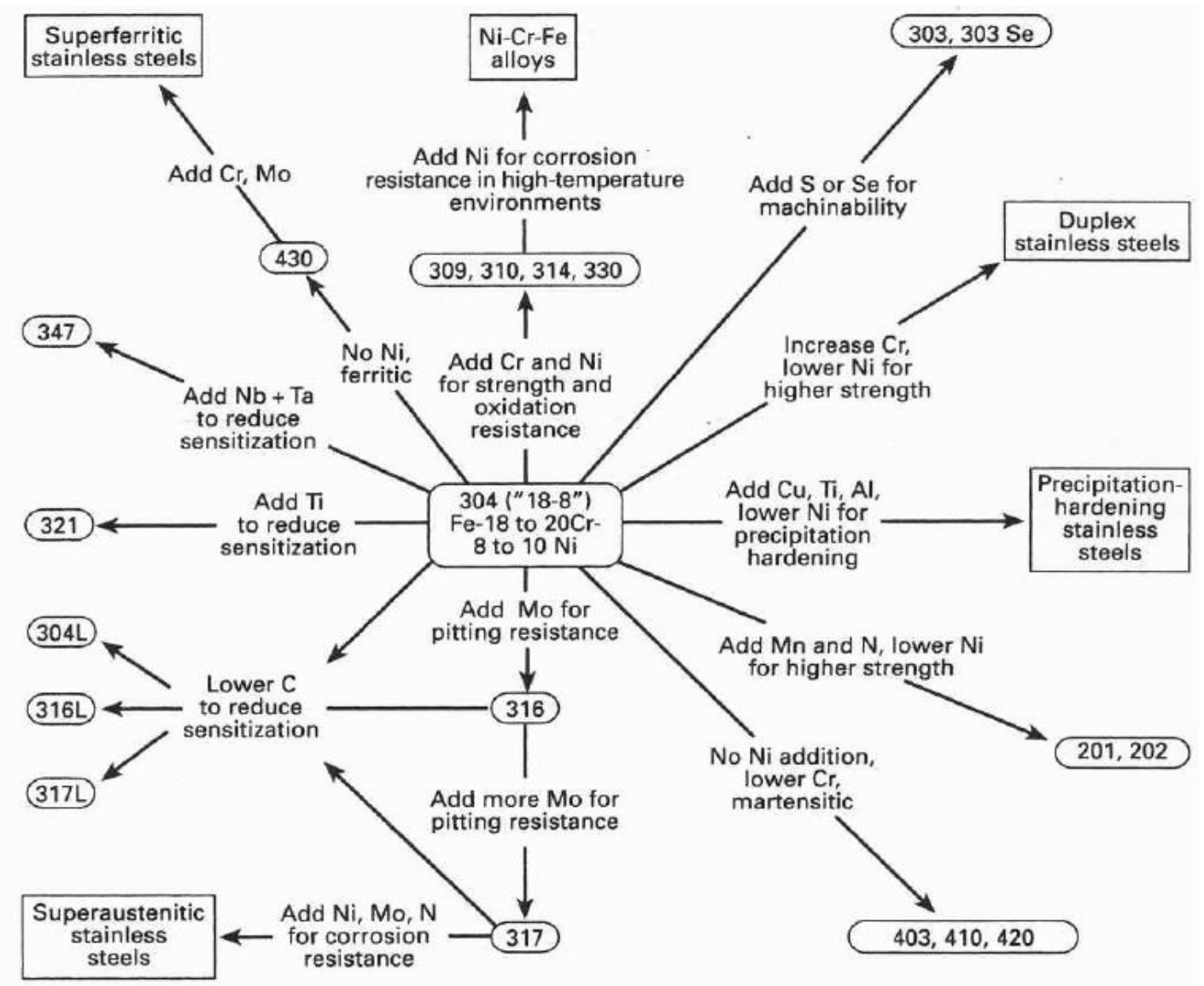

Figure 1-The family tree of SS grades [31]

from 304 , as it contains molybdenum, which is added for corrosion resistance. All three grades have $\mathrm{Fe}, \mathrm{Cr}$, and oxygen at the surface,

In addition to standardizing by composition, stainless steel has a system for standardization of finishes. They are divided into two main classes: polished and unpolished, with subdivisions based on unique processing methods. In general:

- Unpolished Finishes: 2R, 2J

- Polished Finishes:

1, 2, 2B, 2BA, 2D, 2G,

$$
3,4,6,7,8
$$

Different finishes lead to different geometries and feature size scales that have potential to house organisms. One variable does not explain the entire process, so while there are plenty of studies in the literature that correlate increased surface roughness to increased populations of microorganisms or elevated rates of biofilm generation, [32] the finish is not simply a physical property, it also has chemical consequences.

For the most common finish, $2 \mathrm{~B}$, the untreated surface is composed of flattened metal grains, with only partially sealed grain boundaries. The partially sealed grain boundaries form a network of subsurface crevices that can serve as niche environments. Untreated surfaces of $3042 \mathrm{~B}$ mill finish have been shown to support growth in these niche environments, whose grain boundary network leads to proliferation of a microorganism across the surface of a material [33]

In addition, stainless steel can undergo additional processing to refine the surface finish. This is most common with the 2B finish, which is unpolished after initial fabrication:

Sandblasting or beadblasting a $2 \mathrm{~B}$ surface often leads to cratered or pitted surfaces, whose diameter varies with the bead blast diameter. Like the untreated 2B finish, steel ball and glass beaded steel $(70-100 \mu \mathrm{m})$ were less resistant to bacterial adhesion compared to electropolished surfaces [35], [36]. For SS 304, with 2B mill finish, processed with different surface treatments afterwards, it was observed that electropolished surfaces were the most resistant to bacterial attachment with few cells are seen via either SEM or AFM and untreated 304 with $2 \mathrm{~B}$ finish was the least resistant, and thus,.most populated [37]. In between were sanded and sandblasted, giving rise to the following relationship: for most- to least- resistant: Electropolished >sanded > sandblasted $>$ untreated

Table 1-Average Roughness for SS Processes

\begin{tabular}{|l|l|}
\hline Process Description & $\mathrm{R}_{\text {average }}[\mu \mathrm{m}]$ \\
\hline Bead Blasted & $1-6$ \\
\hline Electropolished & $0.1-0.8$ \\
\hline
\end{tabular}

Electropolished surfaces are near-featureless relative to the 
size scale of most bacteria, averaging a roughness of less than $0.5 \mu \mathrm{m}$. Much like the microfabricated structures discussed early on in this paper, size matters. Dimensions of most spores and bacteria are larger than $0.5 \mu \mathrm{m}$, so surface chemistry and the presence of appendages aside, a smoother surface should prove to be less hospitable to adhesion.

Table 2-Unpolished SS Surface Finishes [34]

\begin{tabular}{|c|c|c|c|}
\hline $\begin{array}{l}\text { Surface } \\
\text { Finish } \\
\text { Number }\end{array}$ & Process Description & $\begin{array}{l}\text { Visual Finish } \\
\text { Appearance }\end{array}$ & $\begin{array}{l}R_{\text {average }}[\mu \mathrm{m}] \\
\text { (average } \\
\text { roughness) }\end{array}$ \\
\hline 1 & $\begin{array}{l}\text { Hot rolled, heat } \\
\text { treated,shot-blasted } \\
\text { and pickled to } \\
\text { remove scale }\end{array}$ & Dull and Rough & $3.5-7.5$ \\
\hline $2 \mathrm{D}$ & $\begin{array}{l}\text { Cold-rolled, heat } \\
\text { treated, pickled to } \\
\text { remove scale }\end{array}$ & Smooth & \\
\hline $2 B$ & $\begin{array}{l}\text { Cold-rolled, heat } \\
\text { treated, pickled to } \\
\text { remove scale } \\
\text { Most widely used }\end{array}$ & $\begin{array}{l}\text { Smoother than } \\
\text { 2D }\end{array}$ & $0.3-0.5$ \\
\hline $2 \mathrm{G}$ & $\begin{array}{l}\text { Ground surface-- } \\
\text { grit set by specific } \\
\text { application }\end{array}$ & $\begin{array}{l}\text { Unidirectional } \\
\text { texture, not } \\
\text { very reflective }\end{array}$ & $\begin{array}{c}\text { Set by } \\
\text { application }\end{array}$ \\
\hline $2 \mathrm{R}(2 \mathrm{BA})$ & $\begin{array}{l}\text { Cold-rolled and } \\
\text { bright annealed in } \\
\text { an inert atmosphere } \\
\text { Commonly used } \\
\text { finish. } \\
\text { Ultra smooth } \\
\text { surface less likely to } \\
\text { harbor airborne } \\
\text { contamination and } \\
\text { is easy to clean }\end{array}$ & $\begin{array}{l}\text { Smooth and } \\
\text { reflective }\end{array}$ & \\
\hline $2 \mathrm{~J}$ & $\begin{array}{l}\text { Brushed or dull } \\
\text { polished, set by } \\
\text { application }\end{array}$ & $\begin{array}{l}\text { Unidirectional } \\
\text { texture, not } \\
\text { very reflective }\end{array}$ & $\begin{array}{c}\text { Set by } \\
\text { application }\end{array}$ \\
\hline
\end{tabular}

These size and geometric scale details are important, since it may be possible to select a removal method that takes advantage of alignment (e.g. wiping direction) or relative size scale (e.g. dialing in an appropriate particle size for $\mathrm{CO}_{2}$ snow cleaning).

Since surfaces are not static, roughness has not always been shown to be the limiting factor for adhesion and biofilm formation. For this reason, any design process should factor in the duration of use and duration of exposure in a given environment [40].
Table 3-Polished SS Surface Finishes

\begin{tabular}{|c|c|c|c|}
\hline $\begin{array}{l}\text { Surface } \\
\text { Finish } \\
\text { Number }\end{array}$ & $\begin{array}{l}\text { Process } \\
\text { Description }\end{array}$ & $\begin{array}{l}\text { Visual } \\
\text { Finish } \\
\text { Appearanc } \\
\text { e }\end{array}$ & $\begin{array}{l}\mathrm{R}_{\text {average }} \\
{[\mu \mathrm{m}]} \\
\text { (average } \\
\text { roughness) }\end{array}$ \\
\hline 3 & $\begin{array}{l}\text { Mechanically } \\
\text { polished or rolled. } \\
\text { If mechanically } \\
\text { polished, } 50 \text { or } 80 \\
\text { grit is used, } \\
\text { followed by } 100 \text { or } \\
120 \text { grit abrasives. }\end{array}$ & $\begin{array}{l}\text { Linearly } \\
\text { textured: } \\
\text { Short and } \\
\text { relatively } \\
\text { coarse } \\
\text { parallel } \\
\text { polishing } \\
\text { lines }\end{array}$ & $\begin{array}{l}\leq 1.2 \text { (lower } \\
\text { bound set by } \\
\text { application) }\end{array}$ \\
\hline 4 & $\begin{array}{l}\text { Mechanically } \\
\text { polished or rolledlf } \\
\text { mechanically } \\
\text { polished, No. } 3 \\
\text { finish is polished } \\
\text { with progressively } \\
\text { finer grit, ranging } \\
\text { from } 120-320 \text { grit }\end{array}$ & $\begin{array}{l}\text { Linearly } \\
\text { textured: } \\
\text { Short, } \\
\text { parallel } \\
\text { polish lines, } \\
\text { moderately } \\
\text { reflective } \\
\text { finish }\end{array}$ & $\leq 0.6$ \\
\hline 5 & $\begin{array}{l}\text { Architectural } \\
\text { finish, so variable } \\
\text { processes }\end{array}$ & Variable. & $\begin{array}{c}\text { Transversely, } \\
\text { typically } \leq \\
0.6 \\
\end{array}$ \\
\hline 6 & $\begin{array}{l}\text { Tampico brushing } \\
\text { of a Grade } 4 \text { finish }\end{array}$ & $\begin{array}{l}\text { Soft, satin } \\
\text { finish, } \\
\text { relatively } \\
\text { short } \\
\text { polishing } \\
\text { lines visible. } \\
\text { Lower } \\
\text { reflectivity } \\
\text { compared to } \\
\text { number } 4 \\
\text { finish. } \\
\text { No longer in } \\
\text { production. }\end{array}$ & \\
\hline 7 & $\begin{array}{l}\text { Number } 4 \text { finish } \\
\text { polished to a } 320 \\
\text { grit then buffed } \\
\text { for } 10 \text { minutes }\end{array}$ & $\begin{array}{l}\text { Highly } \\
\text { reflective, } \\
\text { mirror-like, } \\
\text { some } \\
\text { polishing } \\
\text { lines maybe } \\
\text { visible } \\
\end{array}$ & $\leq 0.3$ \\
\hline 8 & $\begin{array}{l}\text { Number } 4 \text { finish } \\
\text { polished to a } 320 \\
\text { grit and then } \\
\text { buffed for } 10 \\
\text { minutes longer } \\
\text { than Grade } 7 .\end{array}$ & $\begin{array}{l}\text { Highly } \\
\text { reflective, } \\
\text { mirror-like, } \\
\text { with few to } \\
\text { no polishing } \\
\text { lines visible }\end{array}$ & $\leq 0.3$ \\
\hline
\end{tabular}

Aluminum - Like stainless steel, aluminum has a range of alloys, with various alloying elements and a standard nomenclature that reflects compositional variations. The properties of a given aluminum alloy can be enhanced by heat or by cold-rolling, labeled as heat-treatable or non-heat treatable, respectively.

There have been limited investigations of the use of aluminum for biological, medical and dental applications, since aluminum has been observed to be unsupportive of biological activity. [41]

Since Al-6061 is commonly used in spaceflight 
applications, there are a few relevant references for planetary protection that we can cite here. The use of aluminum for spaceflight materials in a harsh environment is exemplified by the materials selection choices made for wheels on the family of Mars rovers. In the MER-class of rovers, aluminum was coated with a MIL-SPEC 5541F iridite coating. Studies of $B$. subtilis spores in a Marsrelevant environment show that the hydrophobic surface produced by the iridite coating may be capable of sustaining a community of B.subtilis, as clusters or aggregates on rover wheels [43], which can impart self-protection against the short penetration depth of UV radiation on the Martian surface. This has been shown for the Bacillus family as it relates to concerns biosafety on Earth [44].

Table 4-Summary of Aluminum Alloys [42]

\begin{tabular}{|c|c|c|c|}
\hline $\begin{array}{l}\text { Alloy } \\
\text { Series }\end{array}$ & $\begin{array}{l}\text { Alloying } \\
\text { Element }\end{array}$ & $\begin{array}{l}\text { Heat } \\
\text { Treatable? }\end{array}$ & Comments \\
\hline $1 \mathrm{XXX}$ & $\begin{array}{l}\text { None } \\
\text { (pure) }\end{array}$ & $\begin{array}{l}\text { Heat- } \\
\text { Treatable }\end{array}$ & \\
\hline $2 \mathrm{XXX}$ & $\mathrm{Cu}$ & \multirow{4}{*}{$\begin{array}{l}\text { Non-Heat } \\
\text { Treatable }\end{array}$} & Aircraft skins \\
\hline $3 X X X$ & $\mathrm{Mn}$ & & $\begin{array}{l}\text { Beverage cans, } \\
\text { storage tanks }\end{array}$ \\
\hline $4 X X X$ & $\mathrm{Si}$ & & \\
\hline $5 X X X$ & $\mathrm{Mg}$ & & \\
\hline $6 X X X$ & $\mathrm{Mg}, \mathrm{Si}$ & \multirow{2}{*}{$\begin{array}{l}\text { Heat- } \\
\text { Treatable }\end{array}$} & $\begin{array}{l}\text { Most commonly } \\
\text { used }\end{array}$ \\
\hline $7 X X X$ & $\mathrm{Zn}$ & & \\
\hline $8 X X X$ & $\mathrm{Li}$ & Variable & Aerospace/Aircraft \\
\hline
\end{tabular}

Titanium - The behavior of titanium, titanium nitride (TiN) and titanium dioxide have shown contradicting results with regards to the degree of microbial adhesion. The most common titanium used for spaceflight applications, Ti $6 \mathrm{AL}-4 \mathrm{~V}$, has shown that when inoculated with B.subtilis spores, efforts to clean $\mathrm{Ti}$ are not successful when the surface is cleaned with isopropyl alcohol or with water. In particular, when a particular method of cleaning is used, the solution breaks spores open and serves as a culturing medium for B. Subtils spores. [45]. It is this author's belief that additional work examining the surface roughness and the compositional variation, given the co-existence of metallic $\mathrm{Ti}$, and non-metallic anatase and rutile $\mathrm{TiO}_{2}$ on most Ti surfaces, unless specific controls are in place, leads to such a variation.

Silver-Silver has been shown to be an antibacterial element that has been in sustained use in the medical field topically and as a coating since $4000 \mathrm{BC}$, as a way to the minimize the number vegetative cells able to adhere to a surface. [46]. When it comes to spores, silver surfaces of a wide range of roughnesses have not shown any effect [47].

Copper-Copper has microorganism-dependent responses. In many microbial populations, copper is seen to inhibit growth rates, independent of finish [48],[49],[50]. In bacterial populations, it has been also seen to increase population growth rates [51]. When alloyed, increased copper concentrations have been shown to correlate with increased antimicrobial activity. [52]. While the use of copper in spaceflight applications may seem to be a panacea for planetary protection, its efficacy is only as good as the ability to maintain cleanliness [53].

Gold-Gold is often viewed as a non-reactive, inert metal. Unlike it's other precious metal counterpart, silver, gold is non-toxic to terrestrial microbes [54].

In the end, materials selection with a planetary protection mindset is similar to the concerns that arise in other environmental considerations taken into account (for example, launch loads or thermal loads). In this case, planetary protection is concerned with minimizing the impact of microbial loads appropriate to the requirements of the mission.

\section{They Ate Us OUT OF House ANd HoMe: MICROBIALLY-INDUCED CORROSION}

Unlike particles, microbes are able to consume and metabolise materials that they are in contact with, transforming them chemically, leading to damage to that material's surface. This is known as microbially induced corrosion. Discovered in 1934 [55], microbially induced corrosion is common in a wide variety of metals, including aluminum and stainless steel, in aqueous and non-aqueous environments, including jet fuel and for both aerobic and anaerobic bacteria [56], [57], [58]. It typically results from a galvanic difference between a surface and a microorganism that results in the microorganism using the charge differential to facilitate a metabolic process [59]. For example, among the more common are microbes capable of reducing iron-, sulfur-, perchlorate- and nitrate-bearing components in the substrate or fluid medium [60]. This has been taken advantage of in the waste processing industry, particularly with perchlorate-reducing species [61], [62], [63].

Among the best examples of microbially-induced corrosion is the interaction of stainless steel of various grades with anaerobic sulfur reducing bacteria (SRB) [64]. The metabolism of an SRB is able to take in sulfate in stainless steel and reduce it to sulfide. In situations where there is hydrogen produced by an alternate process, the source of extra protons further promotes the growth of SRBs, further driving the corrosion process [65]. When both SRBs and iron-reducing bacteria are present, there is a synergistic effect, driving up corrosion rates compared to SRBs or ironreducing bacteria alone, even with comparable population sizes. [66], [67],[68]. In addition to iron and sulfur, welded portions of stainless steel can be particularly enticing to certain organisms - it has been observed that for 304L stainless steel, corrosion can proceed by manganese oxidizing organisms [69], [70]; [71].

Materials selection for long-term sample storage and 
handling (where long-term is understood for Earth-based systems to mean 90 days or more) needs to account for the potential for microbially induced corrosion. From a practical standpoint, this would mean that engineering, science and planetary protection team members would have to work together to assess the relative risk associated with materials selection for a storage container weighed against the currently understood metabolic behaviors of extant life forms (terrestrial or otherwise). A good example can be found in some of the current hypotheses of Martian habitability, which also involve the potential Martian microorganisms capable of metabolizing iron- or sulfurbearing components [72], [73]; [74]. A summary of the periodic table and the metabolic behavior of various microbes when exposed to those elements can be found here [75].

In general, the corrosion rates of SRBs on stainless steel range from 0.2- $0.7 \mathrm{~mm} /$ year [76]. Over a 10 year timespan, assuming a constant rate of metabolism, would result in a 2-7 mm loss of stainless steel. This doesn't account for other microbially-induced corrosion mechanisms or for the fact that sulfide is known to accelerate crack growth rates in stainless steel, even at trace concentrations. Such a loss could result in mechanical and structural changes to a sample tube or container as it awaits its return to earth. Could it be that in making materials choices that are not inclusive of the risk associated with microbe metabolism, that any sample, if not adequately protected, could literally eat itself out of its house and home?

\section{Blow This House Down: FACTORING IN Size SCales When Selecting Cleaning METHODS}

From a practical implementation point of view, knowing both the shape and spacing of surfaces in hardware will influence removal efficiency. For example, for isopropyl alcohol wiping, it is important to consider the direction of wiping and size scale of features on a wipe relative to surface finish. When using other physical removal techniques, particle size for the cleaning method should be considered relative to the size of surface features. For example, $\mathrm{CO}_{2}$ snow cleans based on high-pressure particulates, for which the size scale ranges from 1 - $100 \mathrm{um}$, depending on thermal and flow conditions, that can be dynamically changed during cleaning operations [77]. Given this, specific cleaning methods should be selected to match the size scales specific to microscale features on the physical (as well as chemical) size scales so as to optimize removal efficiency. One can huff and puff at any surface, but if the size and force scales are not factored in, the degree to which a given house may be blown down will vary.

\section{SUMMARY}

In the food processing, dairy and water quality industries, all of the above-discussed factors are carefully considered during the hardware design process. This greatly facilitates maintenance of sterile conditions and minimizes crosscontamination. In any environment involving food there is water, which provides one aspect of environmental support for microbial growth. One may look at how spaceflight hardware is assembled, and wave away the relevance of the above material based on the gleam of cleanrooms and the lack of obvious water sources or microbial contributions, but the many demonstrations of microbial population thriving in cleanrooms should discourage such naiveté.

It is important to note that the majority of spaceflight hardware cleanrooms control for particulates, rather than for organics or microbes, unless special measures are taken and that there is life beyond the piece part assembly that happens in cleanrooms. Sources of moisture and crosscontamination from external sources of microbes (e.g., cleanroom engineers) are present during standard integration and test - thermal vacuum and mechanical vibration testing campaigns, Assembly, Test and Launch Opertations (ATLO) environments and during the launch, cruise, and operational phases of a mission. In these environments, the local atmosphere may not be fully controlled unless specific precautions are taken (for example, during launch, lmicrobial contributions can arise from handling of fairing material or from Environmental Control System (ECS) ducting providing environmental control of air, temperature, and humidity to the spacecraft when mounted to the launch vehicle. During cruise, warming of pressurized enclosures by an Radiothermal Generator (RTG) or insulation during cruise and operations) can provide circulation, humidity and an appropriate temperature. In the above examples, local environment can be sufficient to support growth.

\section{ACKNOWLEDGEMENTS}

D.E.P is grateful to all of the planetary protection engineers and microbiologists across the Agency for their willingness to share common conceptions of thought when working with those who are new to the world of biology.

\section{REFERENCES}

[1] E. Kuhn, A. Ichimura, V. Peng, C. Fritsen, G. Trubl and P. T. Doran, Brine Assemblages of Ultrasmall microbial cells within the ice cover of Lake Vida, Antarctia, Applied and Environmental Biology,. 80, 3687-3698, (2014).

[2] G. Hornek, et al. Protection of Bacterial Spores in Space, a Contribution to the Discussion on Panspermia, Origins of life and evolution of the biosphere, 31, 527-547 (2001) . 
[3] RM Donlan, JW Costerton, Biofilms: survival mechanisms of clinically relevant microorganisms, Clin Microbiol Rev., 15, 167-93. (2002).

[4] W. Michael Dunne, Jr., Bacterial Adhesion: Seen Any Good Biofilms Lately? Clin. Microbiol. Rev, 15, 155166 (2002).

[5] NASA Handbook 6022B,, Handbook for the Microbial Examination of Spacecraft Hardware (2010).

[6] J. Jacobs Three Little Pigs, in English Fairy Tale, Oxford University Press, p 68-72 (1890).

[7] U. Ronner and U. Husmark, Adhesion of bacterial spores in relation to hydrophobicity; Biofouling $\mathbf{5}$, 335-344 (1990).

[8] G. Parkar., S.H. Flint, J.S. Palmer, J.D. Brooks, J Factors influencing attachment of thermophilic bacilli to stainless steel, ournal of Applied Microbiology, 90 , 901 (2001).

[9] K. Weincek, N.A. Klapes, P. M. Flint, J. Palmer, K. Bloemen, J. Brooks, and R. Crawford, The growth of Bacillus stearothermophilus on stainless steel, Journal of Applied Microbiology 90, 151-157 (2001).

[10] See for example, P. Simmonds, et al. Heat resistance of Bacillus Spores When Adhered to Stainless Steel and Its Relationship to Spore Hydrophobicity J. Food Protection, 66 2070-2075 (2003).

[11] K. R. Kerney and A.C. Schuerger, Survival of Bacillus subtilis endospores on Ultraviolet-Irradiated Rover Wheels and Mars Regolith under simulated Mars conditions, Astrobiology 11, 477-485 (2011);

[12] K. Venkateswaran, S. Chung, J. Allton, R. Kern, Evaluation of various cleaning methods to remove Bacillus spores from spacecraft hardware materials, Astrobiology 4377 - 399 (2004) .

[13]

Dewi P. Bakker, Bart R. Postmus, Henk J. Busscher, and Henny C. van der Mei, Bacterial Strains Isolated from Different Niches Can Exhibit Different Patterns of Adhesion to Substrata J. Applied and Environmental Microbiology, 70, 3758-3760 (2004).

[14] K. A. Whitehead et al. Retention of microbial cells in substratum surface features of micrometer and submicrometer dimensions, Coll Surf B - Biointerfaces 41 129-138 (2005).

[15] X. Ge, Y Leng, X. Lu, F. Ren, K. Wang, Y. Ding, M. Yang, Bacterial responses to periodic micropillar array, J Biomed Mater Res Part A 103A 384-396 (2015).

[16] A.K. Epstein et al, Control of bacterial biofilm growth on surfaces by nanostructural mechanics and geometry, Nanotechnology 22, 494007, (2011)

[17] H. Gu and D. Ren Front. Chem. Sci. Eng. 2014, 8(1): 20-33

[18] X. Ge, Y Leng, X. Lu, F. Ren, K. Wang, Y. Ding, M. Yang, Bacterial responses to periodic micropillar array, J Biomed Mater Res Part A 103A:384-396 (2015)

[19] L.C. Hsu et al. , April 2013 Volume 79 Number 8 Applied and Environmental Microbiology p. 27032712

[20] S.H.H.Flint, J.D.D.Brooks, P.J.J. Bremer, Properties of the stainless steel substrate, influencing the adhesion of thermo-resistant streptococci. J. Food Eng. 43, 235-242 (2000)

[21] Hochella, MF, et al. Am. Mineralog. 74 1233-1246 (1989)

[22] Boulange-Petermann et al, Adhesion of streptococcus thermophilus to stainless steel with different surface topography and roughness Biofouling: The Journal of Bioadhesion and Biofilm Research, 11, 201-216 (1997)

[23] C. Díaz, M. Cortizo, P. Schilardi, S. Gomez de Saravia, M.A. Fernández Lorenzo de Mele, Influence of the nano-micro structure of the surface on bacterial adhesion. Mater. Res. 10:11-14 (2007)

[24] A.I. Hochbaum and J. Aizenberg .Bacteria pattern spontaneously on periodic nanostructure arrays. Nano Lett. 10, 3717-3721 (2010)

[25] .N. Nakamura, Survival of Shigella sonnei on cotton, glass, wood paper and metal at various temperatures, J. Hyg. 60 35-39 (1962)

[26] AH Weerkamp et al The role of surface energy in the early in vivo formation of dental plaque on human enamel and polymeric substrata Microbial Ecol Health Dis 2 11-18, (1989)

[27] M. Quieryen et al, The influence of surface free energy on planimetric plaque growth in man, J. Dent Res 68, 796-9 (1989)

[28] T.R. Wilkinson, Survival of Bacteria on Metal Surfaces Applied Microbio 14, 303-307 (1966)

[29] D.C. Hansen, Biological Interactions at Metal Surfaces, JOM, vol.. 63, no. 6.June 2011, 22-27

[30] J.D. Redmond, Metals and Alloys in the Unified Numbering System, 10 ${ }^{\text {th }}$ Edition, 2004, Joint Publication of the Society of Automotive Engineers, Inc. and the American Society for Testing and Materials

[31] J. Beddoes and J. G. Parr, Introduction to Stainless Steels, 1999, ASM International, Materials Park, OH.

[32] W. Arnold, D.H. Boothe and G.W. Bailey, Parameters of stainless steel surfaces important for resistance to bacterial contamination, Trans. ASAE, 44 347-356 (2001)

[33] C. Jullien, et al. Identification of surface characteristics relevant to the hygienic status of stainless steel for the food industry, J. Food Eng. 56, 77-87 (2003)

[34] From the standard, EN-10088-2 and C. Honess, Importance of Surface Finish in the Design of Stainless 
http://www.bssa.org.uk/cms/File/surfacefinishbssaVer 2.pdf

[35] Arnold and Bailey Poultry Science 79 1839-1845 $(2000$

[36] JW Arnold and O Suzuki, Transactions of the ASAE 46, 1595-1602 (2003)

[37] JW Arnold, DH Boothe, GW Bailey, Transactions of the ASAE 44 347-356 (2001)

[38] J.W. Arnold and G.W Bailey, Surface Finishes on stainless steel reduce bacterial attachment and early biofilm formation: Scanning electron microscopy and atomic force microscopy study, Poultry Science, 79, 1839-1845 (2000)

[39] K.A. Whitehead and J. Verran The Effect of Substratum Properties on the Survival of Attached Micororganisms on inert surfaces in HC. Flemming (Eds.) Marine and Industrial Biofouling, SpringerVerlag, Berlin Heidelberg 13-33 (2009)

[40] Medilanski et al, Biofouling 18 193-203 (2002)

[41] R.F. Pina and C. Cervantes, Microbial interactions with aluminum, Biometals, 9 issue 3, 311-316 (1996).

[42] http://www.aluminum.org/resources/industrystandards]

[43] K. R. Kerney and A.C. Schuerger, Survival of Bacillus subtilis endospores on Ultraviolet-Irradiated Rover Wheels and Mars Regolith under simulated Mars conditions, Astrobiology 11, 477-485 (2011).;

[44] Wood JP, Meyer KM, Kelly TJ, Choi YW, Rogers JV, Riggs KB, et al. (2015) Environmental Persistence of Bacillus anthracis and Bacillus subtilis Spores. PLoS ONE 10(9): e0138083. doi:10.1371/ journal.pone.013808]

[45] K. Venkateswaran, S. Chung, J. Allton, R. Kern, Evaluation of various cleaning methods to remove Bacillus spores from spacecraft hardware materials, Astrobiology 4377 - 399 (2004)

[46] J.W. Alexander, History of the medical use of silver, Surg. Inf. 10 289-292 (2009).

[47] B. Galeano et al., Inactivation of vegetative cells, but not spores of Bacillus anthracis, B. cereus, B. subtilis on stainless steel surfaces coated with an antimicrobial silver- and zinc- containing zeolite formation, Appl. And Env. Microbiol. 69, 4329-4331 (2003) ]

[48] G. Grass, C. Rensing, M. Solioz, Metallic copper as an antimicrobial surface, Appl. And Envir. Microbiol. 77 , 1541-1547 (2011);

[49] R.B. Jonas Acute copper and cupric ion toxicity in an esuraine microbial community, Appl. Env. Microb. 55 43-49 (1989);

[50] L.J. Wheedon, Antimicrobial efficacy of copper surfaces against spores and vegetative cells of $C$. Difficile: the germination theory. J. Antimicrob. Chemo. 62, 522-525 (2008)
[51] T.J. Starr and M.E. Jones the effect of copper on the growth of bacteria isolated from marine environments Limnol Oceanog 2 33-36 (1957)

[52] S.A. Wilks et al. The survival of E. Coli on a range of metal surfaces, Int J. Food Microbiol 105 445-454 (2005)].

[53] SV Avery et al. Copper toxicity towards S. cervisiae dependence on plasma membrane fatty acid composition, Appl Env Microbiol 62 3960-3966 (1996) ]

[54] Y, Zhao X:Cytotoxicity of photoactive nanoparticles .In Safety of Nanoparticles: From Manufacturing to Medical Applications Edited by Webster T. Springer Science + Business Media, LLC, 233 Spring St.:New York, NY 10013;2008:19-31].

[55] C. A. H. von Woizogen Kuhr and L. S. van der Vlugt, Water, 18, 1147 (1934)],

[56] T.R. Jack, Biological Corrosion Failures, ASM Handbook volume 11881 (2002)

[57] T.S. Rao, Microbiologically Influenced Corrosion: Basics and Case Studies, Corrosion Reviews, 333365 (2009)

[58] T.R. Jack, Chapter 6 in A Practical Manual on Microbiologically Influenced Corrosion, Vol 2, J.G. Stoecker II, Ed., National Association of Corrosion Engineers International, 2001

[59] D.A. Jones and P.S. Amy, Related Electrochemical Characteristics of Microbial Metabolism and Iron Corrosion, Ind. Eng. Chem. Res., Vol 39, 2000, p $575-582$.

[60] S.R. Freeman and H. Thielsch, Microbiological Activity and Chlorides Cause Carbon Steel Pipe Pitting, Mater. Perform., Vol 35 (No. 3), 1996, p 6566.

[61] Benedict C. Okeke, Tara Giblin, William T. Frankenberger Jr, Reduction of perchlorate and nitrate by salt tolerant bacteria, Environmental Pollution 118 (2002) 357-363

[62] B.E. Logan, J. Wu and R.F. Unz, Biological Perchlorate Reduction in High-Salinity Solutions, Wat. Res. 35, 3034-3038 (2001),

[63] Y. Cang, D.J. Roberts, D.A. Clifford, Development of cultures capable of reducing perchlorate and nitrate in high salt solutions, Water Research 38 (2004) 3322-3330.

[64] D. Enning, J. Garrelfs, Corrosion of Iron by SulfateReducing Bacteria: New Views of an Old Problem, Applied and Environmental Microbiology 80, 12261236 (2014).

[65] .A. Hardy, Utilization of Cathodic Hydrogen by Sulphate-Reducing Bacteria, Br. Corros. J., Vol 18, 1983, p 190-193.

[66] C. Xu, Y. Zhang, G. Cheng, W. Zhu, Materials Characterization 59 245-255 (2008);

[67] T.S. Rao, T.N. Sairam, B. Viswanathan, K.V.K Nair, 
Corrosion Science 42 1417-1431 (2000)

[68] ; A. Steele, D.T. Goddard, I.B. Beech, An atomic force microscopy study of the biodeterioration $f$ stainless steel in the presence of bacterial biofilms., Intl J. Biodeterioration and Biodegradation 34 35-46 (1994)]

[69] B.H. Olesen, P.H. Nielsen, and Z. Lewandowski, Effect of Biomineralized Manganese on the Corrosion Behaviour of C1008 Mild Steel, Corrosion, Vol 56 (No. 1), 2000, p 80-89

[70] D.T. Ruppel, S.C. Dexter, and G.W. Luther III, Role of Manganese Dioxide in Corrosion in the Presence of Natural Biofilms, Corrosion, Vol 57 (No. 10), 2001, p 863-873

[71] C. Zhigang, P. Gumpel, and M. Kaesser, Microbiologically Influenced Corrosion of Weld on Stainless Steel 304L, Chin. J. Mech. Eng. (Engl. Ed.), 11, 159-164 (1998)

[72] Charles S. Cockell, Trajectories of Martian Habitability, Astrobiology, 14, 182-203 (2014)

[73] An Astrobiology Strategy for the Exploration of Mars By Committee on an Astrobiology Strategy for the Exploration of Mars, Space Studies Board, Board on Life Sciences, Division on Engineering and Physical Sciences, Division on Earth and Life Studies, National Research Council, for example, pg 43 (2007)

[74] The Limits of Organic Life in Planetary Systems; By Committee on the Origins and Evolution of Life, Committee on the Limits of Organic Life in Planetary Systems, Space Studies Board, Board on Life Sciences, Division on Engineering and Physical Sciences, Division on Earth and Life Studies, National Research Council for example, page 85, (2007).

[75] L.P. Wackkett, A.G. Dodge and L. B.M Elliot, Microbial Genomics and the Periodic Table, Appl. Env. Microbiol. 70, 647-644 (2004)]

[76] T.R. Jack, Chapter 6 in A Practical Manual on Microbiologically Influenced Corrosion, Vol 2, J.G. Stoecker II, Ed., National Association of Corrosion Engineers International, 2001

[77] YH Liu J. Aerosol Sci 48, 1-9 (2012)..

\section{BIOGRAPHY}

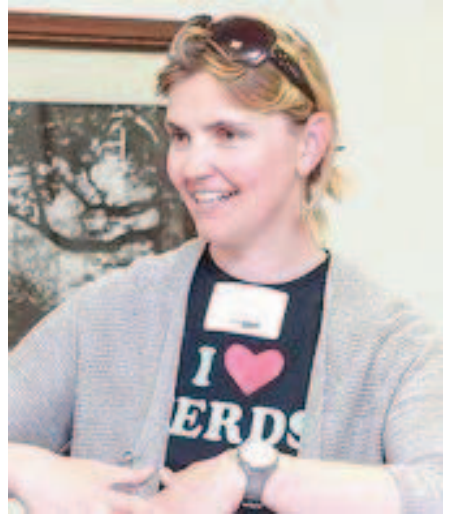

D.E. (Betsy) Pugel received her B.S. in physics from the University of Michigan and Ph.D. in experimental condensed matter physics with a focus on the interaction between metal oxide surfaces and ultraviolet spectroscopy from the University of MarylandCollege Park. Since coming to NASA in 2002, she has enjoyed the range of projects and roles that she has played-from engineer, to scientist to project manager. She has started her third year working in the Office of Planetary Protection at NASA Headquarters as the Deputy to the Planetary Protection Officer.

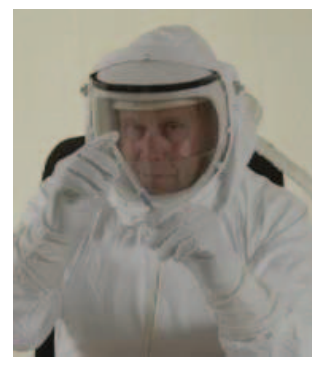

John D. Rummel received a B.A. in Environmental Biology from the University of Colorado, Boulder, in 1974. After serving as a Naval Flight Officer he began his dissertation research at Stanford University, and earned his doctorate in evolutionary ecology in 1985, the same year he joined NASA Ames as an NRC Research Associate, studying controlled ecological life support systems. Moving to NASA Headquarters in 1986 he ran NASA's Exobiology Program and other duties (including being NASA's Planetary Protection Officer [PPO]) until 1994, when he went to the Marine Biological Laboratory in Woods Hole, Massachusetts. Returning to Headquarters as PPO in 1998 he became Senior Scientist for Astrobiology in 2006, and left NASA for East Carolina University in 2008, retiring from ECU in 2015. 


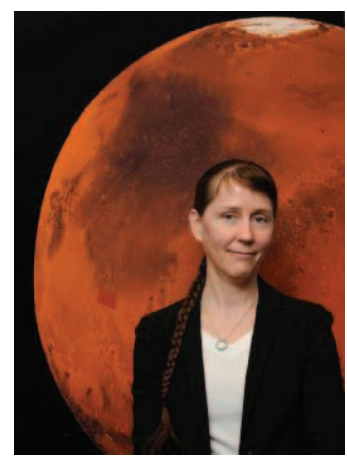

Catharine Conley is

NASA'sPlanetary Protection

Officer. Conley's research at NASA Ames Research Center focused on the biochemistry and evolution of muscle tissue, the basis for motility in all multicellular organisms. A recent offshoot of this work explores the adaptation of multicellular organisms to extreme environments,

including the Atacama Desert in South America and the Arctic tundra. Dr. Conley has been involved in several spaceflight experiments using the nematode worm Caenorhabditis elegans, the first of which was flown on the last mission of the Space Shuttle Columbia. Flight hardware was recovered after the tragic accident, and when opened it was seen that the spaceflown experimental animals were still alive, a finding of considerable relevance to Planetary

Protection. In 1999, Dr. Conley joined NASA after completing postdoctoral studies at the Scripps Research Institute in La Jolla, CA, where she characterized afamily of proteins involved in regulating the actin cytoskeleton that are required for proper muscle contraction. Dr. Conley received a Ph. D. in Plant Biology in 1994 from Cornell University in Ithaca, NY, where her graduate research focused on characterizing functional defects in petunias that are mutant for male sexual reproduction. She earned two B.S. degrees from the Massachusetts Institute of Technology, one in Life Sciences and one in Humanities, involving a major in Russian and French languages and a minor in music performance. 
